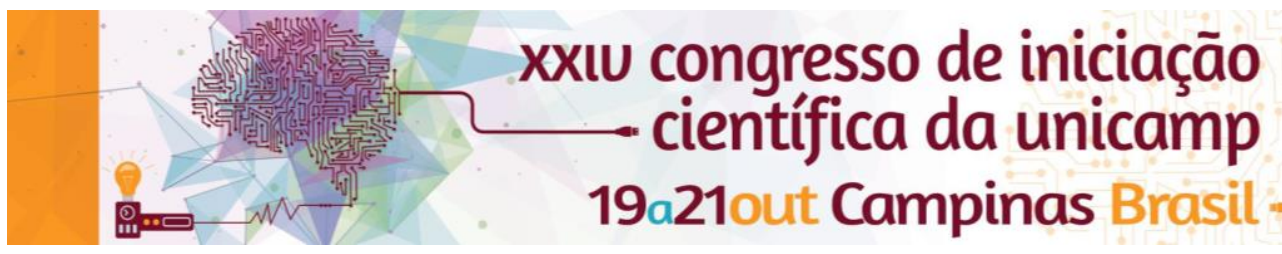

\title{
As relações sociais no emprego doméstico: da labuta à luta
}

\begin{abstract}
Resumo
Através da análise da recente produção cinematográfica, mais especificamente do filme de 2015 "Que Horas ela volta?" e de levantamento bíbliográfico sobre o tema do emprego doméstico e da relação entre produção artística e sociedade, buscou-se compreender qual a importância de uma análise sociológica do cinema - e de outras formas de produção artística, devido a sua relação dialética de representação e influência no contexto social e político. Foi ainda inevitável estabelecer alguns questionamentos referentes aos limites da representatividade e buscar compreender nas mãos de quem se encontram tais ferramentas, a fim de debater se a visibilidade, por si só, se constituiria enquanto ferramenta efetiva que dá voz aos grupos oprimidos representados, neste caso, as empregadas domésticas.
\end{abstract}

Palavras-chave: Emprego doméstico, representação, estudos subalternos.

\section{Introdução}

Em estudos anteriores, foi possível concluir que parte das dificuldades a que estavam submetidas as trabalhadoras domésticas era consequência de um histórico de invisibilidade, o que impediu que fossem reconhecidos seus direitos - em paridade com outras categorias trabalhistas.

Os últimos anos, no entanto, foram marcados por processos econômicos e sociais que trouxeram maior atenção para as classes populares, havendo uma ascensão das classes C e D. Este contexto social se refletiu na imagem e nas representações encontradas sobre as trabalhadoras domésticas na indústria cultural do país - tanto na imprensa quanto na produção cinematográfica e de telenovelas.

\section{Resultados e Discussão}

Através da análise da bibliografia foi possível perceber que a arte tanto se interessa pelos problemas sociais, como é influenciada pelo meio, representando esta influência de diversas maneiras - narrativamente ou tecnicamente. Sendo capaz de influenciar, produzir ou reproduzir na sociedade uma determinada conduta, podendo gerar mudanças nas em sua estrutura social, nas concepções de mundo dominantes e reforçar valores e ideologias, as distintas formas artísticas, e o filme em especial, podem ser consideradas tanto ferramentas de participação política, quanto instrumentos de análise sociológica.

A análise do filme "Que Horas Ela Volta?", permite diversas possibilidades de discussão sobre a situação da empregada doméstica e, consequentemente, sobre as opressões de gênero e classe. Tendo sido produzido e distribuído por instituições hegemônicas e, apesar de ter como foco o emprego doméstico, o filme possui linguagem e símbolos comuns à classe média e alta brasileira.

Alguns dos pontos centrais abordados na análise do filme foram:

A problematização da questão da construção social da identidade feminina enquanto realidade heterogênea. O filme apresenta três mulheres no centro de um debate sobre relações hierárquicas, permitindo-nos pensar sobre alguns elementos da construção dessas identidades provenientes de diferentes realidades sociais e culturais.
A bipolarização da inserção feminina no mercado de trabalho, ao observar duas classes distintas de mulheres conciliando suas jornadas de trabalho com sua vida familiar.

A relação entre a família dos patrões e a trabalhadora doméstica, que apesar da proximidade do cotidiano, está marcada por separação hierárquica, no espaço da casa e no trabalho.

Pensar sobre a interseccionalidade das opressões de gênero e classe e origem regional devido a migração, não somente percebidas nas relações entre patroa $e$ empregada, mas também entre diferentes empregados domésticos, no caso do filme podemos encontrar pelo menos três ocupações distintas, uma faxineira, uma babá e um motorista.

A naturalização de aspectos da subordinação da empregada que é quebrada com a chegada da filha, permitindo a tomada de consciência da trabalhadora.

Discutir a abordagem sobre a mudança de vida dos personagens, que não passa pela mobilização coletiva, e sim pelo esforço individual seja da filha jovem que faz o vestibular, seja da trabalhadora ao pedir demissão e buscar outra profissão.

\section{Conclusões}

Apesar da representatividade e da visibilidade possuírem importância para grupos marginalizados enquanto abertura de espaço para discussões como as desenvolvidas neste trabalho, estas, por si só, não garantem que tais grupos terão espaço de fala, existindo a possibilidade de estes permanecerem silenciados enquanto outros falam deles e por eles.

Assim, é necessário observar a produção cultural enquanto espaço de disputa, no qual as identidades são afirmadas, recriadas e modificadas. Constituindo-se como ferramentas de dominação, mas também de resistência.

\section{Agradecimentos}

Agradeço a atenção e paciência na orientação da Prof $^{a}$ Ângela Araújo e ao fomento do CNPQ.

\section{Agradecimentos}

Jordão, J. 2008; Macedo, R 2015; Cândido, A. 1995 